\title{
The Effect of Giving Dadih on Manganese Superoxide Dismutase Gene Expression and Malondialdehyde Levels at Aging Kidney
}

\author{
Harnavi Harun ${ }^{1,2 \star}$, Yanwirasti Yanwirasti ${ }^{3}$, Bambang Purwanto ${ }^{4}$, Endang Purwati Rahayuningsih ${ }^{5}$ \\ ${ }^{1}$ Department of Internal Medicine, Faculty of Medicine, Andalas University, Dr M Djamil Central General Hospital Padang, \\ Indonesia; ${ }^{2}$ Department of Anatomy, Faculty of Medicine, Andalas University, Padang, Indonesia; ${ }^{3}$ Department of Internal \\ Medicine, Faculty of Medicine, Sebelas Maret University, Solo, Indonesia; ${ }^{4}$ Department of Biotechnology, Faculty of Animal \\ Husbandary, Andalas University, Padang, Indonesia; ${ }^{5}$ Faculty of Animal Husbandry, Andalas University, Padang, Indonesia
}

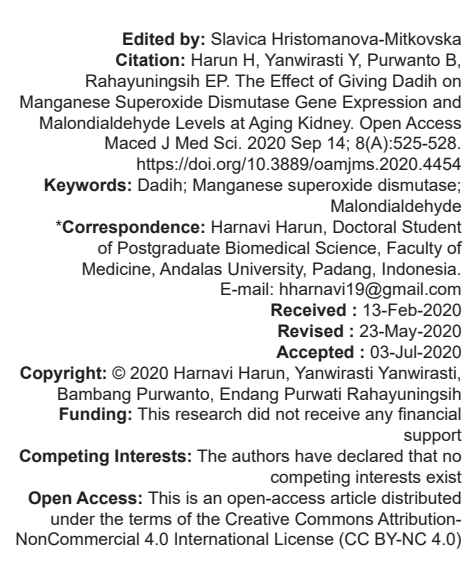

\begin{abstract}
BACKGROUND: The aging process is a complex physiological mechanism that cannot be disclosed in exact detail. Various theories about the aging process have been put forward by many experts.

AIM: This study aims to prove the effect of dadih on manganese superoxide dismutase (MnSOD) gene expression and malondialdehyde levels at aging kidney.

MATERIALS AND METHODS: This study used 30 Rattus norvegicus which were divided into three groups: Group 1 was a positive control (did not get dadih), Group 2 received dadih $1 \times 4.5 \mathrm{~g} /$ day, and Group 3 received dadih $2 \times 4.5 \mathrm{~g}$ day for 42 days. After that, MDA levels of kidney tissue are examined using the thiobarbituric acid reactive substances examination technique and examination of kidney and examination of MnSOD was done by immunohistochemical staining of kidney tissue. Data were analyzed using the normality test with Shapiro-Wilk.

RESULTS: The results showed that dadih were be able to decreased MDA levels in Group 2 and Group 3 compared to Group 1 (control) $0.97 \pm 0.06 \mathrm{pg} / \mathrm{mL}$ to $0.75 \pm 0.03(p<0.05$ ). Dadih also increased MnSOD expression sequentially from Group $133.66 \pm 9.29$ to Group $253.58 \pm 8.51$ and Group $373.70 \pm 4.29(p<0.05)$
\end{abstract}

CONCLUSION: This study concluded that dadih can reduce MDA levels in old kidney tissue and dadih can increase the expression of MnSOD.

\section{Introduction}

The aging process is a complex physiological mechanism that cannot be disclosed in exact detail. Various theories about the aging process have been put forward by many experts. This aging theory continues to develop until the era of the modern aging theory. However, there is not a single theory that can explain the aging process as a whole, one theory supports each other [1,2].

Free radical theory is more widely used and widely accepted as a theory that can better explain the aging process. This theory was later modified by adding the role of mitochondria in the aging process because these organelles are the main source of reactive oxygen species (ROS) production. In its development, the modern aging theory calls this theory an oxidative stress theory [1-3].

As a result of this imbalance between oxidants and antioxidants, oxidative stress will occur, which will produce ROS. Under normal physiological conditions, cells can overcome ROS by various endogenous antioxidant enzymes such as manganese and copper/ zinc superoxide dismutase (MnSOD and $\mathrm{Cu} / \mathrm{ZnSOD}$ ), glutathione peroxidase, and catalase, which then turn into water with glutathione peroxidase or catalase. This enzyme together with antioxidants with small molecular weight, such as glutathione and Vitamins $C$ and $E$, can reduce free radicals [4]. However, this endogenous antioxidant also decreases with age so that as a person ages, more and more free radicals are formed so that damage continues to occur $[1,5,6$,$] .$

Based on the theory of aging, oxidative stress is an important factor that links the decline in kidney function with aging. Oxidative stress will cause oxidative damage that affects the three pillars of cell life, namely, cell membranes, proteins, and DNA. Oxidative damage to cell membranes will produce lipid peroxide. One of its products is malondialdehyde (MDA) $[6,7]$. Research on old mice proves that there is an increase in urine isoprostane levels, decreased SOD expression, and increased renal fibrosis in older mice when compared with young mice, the absence of SOD1 leads to glomerulonephritis, nephrocalcinosis, and lymphocyte infiltration so that it experiences a 
decrease in longevity [8].

Therefore, it can be said that dadih contains antioxidants and can increase natural antioxidants in the body. Based on the background above, the researchers wanted to prove the effect of giving dadiah on MDA and SOD, kidney tissue in the aging kidney.

\section{Materials and Methods}

\section{Samples}

Thirty male white rats (Rattus norvegicus) aged 24 months and weighing $450 \mathrm{~g}$ were divided into three groups. Each group consisted of 10 animals divided into Group K (control group was only given aquadest as a dadih solvent), Group P1 (the treatment group was given dadih as much as $1 \times 4.5 \mathrm{~g} /$ day dissolved in aquadest), and Group P2 (the treatment group is given dadih as much as $2 \times 4.5 \mathrm{~g} /$ day which is dissolved in aquadest). Giving dadih is given for 42 days. Dadih used came from cold water, Alahan Panjang, Solok, West Sumatra.

\section{Examination of MDA levels}

After the kidney tissue of male white rats ( $R$. norvegicus) is collected, it is centrifuged $1.500 \mathrm{rpm}$ for $15 \mathrm{~min}$ and then stored at $-60^{\circ} \mathrm{C}$. Measurement of MDA levels, the serum is done by spectrophotometric methods. The working principle is to use the NWKMDA01 assay based on the reaction of MDA with thiobarbituric acid absorption read with wavelength $\lambda 532 \mathrm{~nm}$.

\section{Immunohistochemistry}

Immunohistochemical staining techniques are indirect immunoperoxidase staining with a three-phase avidin-biotin complex method with the following stages deparaffinization tissue incisions to remove paraffin from the tissue. Deparaffinization is carried out by means of laboratory standard standards, that is, gradually by a certain time put preparations into liquid acetone, xylol, $100 \%$ alcohol, $90 \%$ alcohol, $80 \%$ alcohol, $70 \%$ alcohol, and water and then wash the tissue with phosphatebuffered saline (PBS) $\mathrm{pH}$ 7.4. The tissue is incubated with $0.125 \%$ trypsin at $37^{\circ} \mathrm{C}$ for $5-10 \mathrm{~min}$ to open the masking antigen. The tissue is incubated with $0.5 \% \mathrm{H}_{2} \mathrm{O}_{2}$ in methanol for 30 min to remove endogenous staining and left at room temperature. Wash with running water for 1 min, followed by washing with aquadest. Mark the tissue and wash with PBS pH 7.4 for 5 min. Incubate with $3 \%$ serum dissolved in $1 \%$ bovine serum albumin for 20 min. Wash with PBS pH 7.4 twice, each for 3 min. The tissue is incubated with a primary monoclonal antibody, namely, murine monoclonal antibody to molecules from mice (Santa Cruz, US). Monoclonal antibodies are dissolved with Tris-PBS 1:200. For $1 \mathrm{~cm}^{2}$ tissue $100 \mathrm{~mL}$, monoclonal antibodies are needed. Incubation is carried out for $30 \mathrm{~min}$ in a humid room. Wash the tissue with PBS pH 7.4 twice each of $3 \mathrm{~min}$. The tissue is incubated with primary antibodies, namely, anti-murine antibodies that have been biotinylated (Dako kit) for $30 \mathrm{~min}$. Wash the tissue with PBS $\mathrm{pH} 7.4$ twice each for $3 \mathrm{~min}$. The tissue is incubated with streptavidin-biotin peroxidase (Dako kit) for $30 \mathrm{~min}$. Wash the tissue with PBS pH 7.4 twice each for $3 \mathrm{~min}$. Incubate the tissue with a substrate (Dako kit) until brown color arises in the tissue, for approximately $15 \mathrm{~min}$. Wash the tissue with PBS pH 7.4 twice each for $3 \mathrm{~min}$. Color tissue with hematoxylin. Wash network with running water. Cover the network with a glass cover (deck glass) and glue with glue and positive molecular expression with primary monoclonal antibodies will appear brown under a light microscope with $\times 400$. Positive cells are counted as a percentage [9].

\section{Research ethics}

Ethics clearance was approved by the Ethics Committee of Medical Faculty of Andalas University (No: 152/KEP/FK/2019). Written informed consent was obtained from all subjects before the start of the study after they got information about the procedures.

\section{Data analysis}

The results obtained MDA levels $(\mathrm{pg} / \mathrm{ml})$ and renal interstitial fibrosis in the initial stages were tested for normality with Shapiro-Wilk. If it is not normally distributed, transformation is performed and then the normality test is again performed. If still not normally distributed, the analysis will be non-parametric, and if normal, the parametric test is carried out. If the value of $p<0.05$ means there is significant difference.

\section{Results}

Based on Table 1, there was a tendency to decrease MDA levels in the treatment group when compared to the control group $(\mathrm{K})$, from $0.97 \pm 0.06$ to $0.75 \pm 0.03$. Statistically, this decrease was significant $(p<0.05)$.

Table 1: Effects of giving dadih on MDA levels in kidney tissue based on MDA $(\mathrm{pg} / \mathrm{mL})$ reactions

\begin{tabular}{lllll}
\hline MDA & $\mathbf{n}$ & Average & Standard deviation & $\mathbf{p}$ \\
\hline $\mathrm{K}$ & 10 & 0.97 & 0.06 & 0.001 \\
$\mathrm{P}_{1}$ & 10 & 0.75 & 0.03 & \\
$\mathrm{P}_{2}$ & 10 & 0.75 & 0.03 & \\
Total & 30 & 0.82 & 0.11 & \\
\hline
\end{tabular}




\section{Effects of giving dadih on MnSOD gene expression in kidney tissue}

The effect of giving dadih on MnSOD gene expression in kidney tissue is shown in Table 2.

From Table 2, it can be seen the average increase of MnSOD expression after giving a dadih from control $(33.66 \pm 9.29)$ to treatment $153.58 \pm 8.51$ and subsequently with treatment 2 , namely, $73.70 \pm 4.29$.

Table 2: Effect of giving dadih on MnSOD gene expression in kidney tissue

\begin{tabular}{lllll}
\hline MnSOD & $\mathbf{n}$ & Average & Standard deviation & $\mathbf{p}$ \\
\hline Control & 10 & 33.66 & 9.29 & 0.001 \\
$\mathrm{P}_{1}$ & 10 & 53.58 & 8.51 & \\
$\mathrm{P}_{2}$ & 10 & 73.70 & 4.29 & \\
Total & 30 & 53.64 & 18.20 & \\
\hline \multicolumn{4}{l}{ MnSOD: Manganese superoxide dismutase }
\end{tabular}

Figure 1 showed Immunohistochemical staining of kidney tissue. MnSOD is expressed intracystic plastically on tubular epithelial cells. There was an increase in MnSOD expression in tissues by giving gifts compared to control both in terms of the proportion of colored cells and the intensity of staining. The highest MnSOD expression was found in multiple doses.

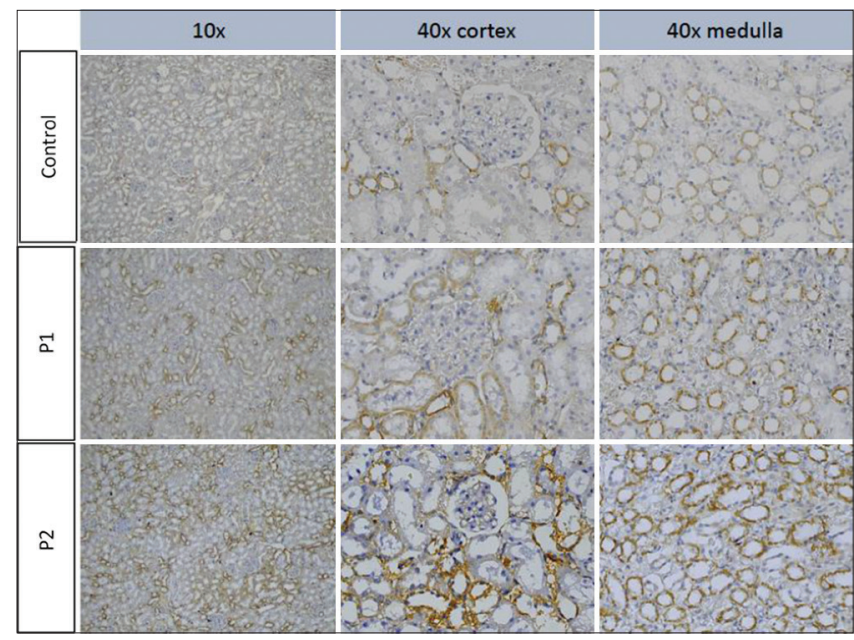

Figure 1: Manganese superoxide dimutase (MnSOD) immunohistochemical staining of kidney tissue in control group, group $P 1$ and group $P 2$

\section{Discussion}

\section{kidney tissue \\ Effect of giving dadih on MDA levels in}

One of the aging's famous theories states that the normal aging process is caused by free radicals that are formed endogenously as a by-product of metabolic processes that use oxygen. Mitochondria play an important role in the aging process because these organelles are the main source of producing free radicals, as a side effect of energy formation. In young mitochondria, this situation can be overcome by the presence of antioxidants found in the body. However, in old mitochondria, it is not enough to produce the antioxidants needed to neutralize free radicals that are formed.

As a result, there is an accumulation of free radicals in the cell so that there is an imbalance between the productions of free radicals with antioxidants. As a result of this imbalance, between the formation of free radicals (reactive oxygen species $=$ ROS) with the required antioxidants, there will be damage to body tissue called oxidative damage. ROS can attack all types of biomolecules, especially unsaturated fatty acids, which are important components of the phospholipids that make up cell membranes.

When free radicals, especially hydroxide radicals, react with these unsaturated fatty acids, there will be a chain reaction known as lipid peroxidation. Decomposition of lipid peroxidation will produce hydroperoxides which will affect membrane function. One of the products of this hydroperoxide is MDA which is a marker of oxidative damage that can be inhibited by giving antioxidants from outside the body.

\section{The effect of dadih on MnSOD levels in kidney tissue in kidney aging}

As a result of aging, mitochondria lose their function as transporting hydrogen and electrons, resulting in the accumulation of free radicals in cells. Under normal circumstances, this can be overcome by increasing the production of antioxidant enzymes in the body. However, in aging, there is also a decrease in the production of antioxidant enzymes which will cause an increase in ROS in the body and cause oxidative damage.

To overcome this situation, exogenous antioxidants are needed. The gifts given in this study have been shown to be antioxidants themselves, while also being able to stimulate the host's antioxidant system and can increase antioxidant activity effectively.

MnSOD is believed to be an antioxidant that functions as a superoxide radical scavenger, where mice lacking MnSOD expression will die within the age of 10-21 days. LeBlanc et al. (2011) found that the administration of $L$. casei BL23 produced SOD in mice that were engineered to suffer from Crohn's disease so that they experienced rapid recovery compared to groups who did not get $L$. casei BL23 [10].

In the body, superoxide is formed through enzymatic and non-enzymatic processes such as transport electrons in the mitochondria hydroxylation reaction in the endoplasmic reticulum, xanthine oxidase reaction in the formation of uric acid, and auto-oxidation of catecholamines which are all important biochemical processes for the survival of the body's physiological processes. MnSOD enzymes function to change 
the superoxide formed in the metabolic process into peroxide $\left(\mathrm{H}_{2} \mathrm{O}_{2}\right)$.

Pure dadih does not have the ability as a catalase to capture $\mathrm{Fe}_{2}^{+}$and $\mathrm{Cu}_{2}^{+}$metal ions so that the formation of hydroxyl radicals still occurs, which will cause an increase in lipid peroxidation which results in MDA. This is different from the research of Lee et al. (2005) and Ahire et al. (2013), which can increase flatfoot $\mathrm{Fe}$ and $\mathrm{Cu}$ ions in the administration of $L$. casei KCTC 3260 and Lactobacillus helveticus CD6 [11,12].

From the results of the study, it showed dadih can reduce MDA levels in old kidney tissue, where this reduction is very significant between groups who get dadih both $1 \times 4.5$ grams per day and groups who get dadih $2 \times 4.5$ grams per day compared to groups that do not get dadih. However, there was no difference in decreasing MDA levels in renal tissue in the group that received $1 \times 4.5$ gram per day and the group that received $2 \times 4.5$ gram per day and dadih can increase the expression of MnSOD in old kidney tissue, where this increase is very significant between groups who get dadih 1 x 4.5 grams per day or groups who get dadih 2 $x 4.5$ grams per day compared to groups that do not get dadih. The increase in the expression of MnSOD that was higher was also very significant in the group that received dadih of $2 \times 4.5$ grams per day compared to the group that received dadih of $1 \times 4.5$ grams per day.

\section{Conclusion}

From the results of the study, it can be concluded that dadih reduced MDA levels and increased the expression of MnSOD in aging kidney tissue.

\section{References}

1. Darmojo RB. Teori proses menua. In: Martono H, Pranarka $\mathrm{K}$, editor. Buku Ajar Boedhi-darmojo Geriatri (IImu Kesehatan Usia Lanjut). $4^{\text {th }}$ ed. Jakarta: Pusat Penerbitan Departemen IImu
Penyakit Dalam Fakultas Kedokteran Universitas Indonesia; 2020. p. 3-13. https://doi.org/10.15395/mkb.v47n2.571

2. Goldsmith TC. Modern evolutionary mechanics theories and resolving the programmed/non-programmed aging controversy. Biochemistry (Mosc). 2014;79(10):1049-55. https://doi. org/10.1134/s000629791410006x

PMid:25519063

3. Stuart JA, Maddalena LA, Merilovich M, Robb EL. A midlife crisis for the mitochondrial free radical theory of aging. Longev Healthspan. 2014;3(1):4. https://doi.org/10.1186/2046-2395-3-4 PMid:24690218

4. Wang Y, Wu Y, Wang Y, Xu H, Mei X, Yu D, et al. Antioxidant Properties of Probiotic Bacteria. Nutrients. 2017;9(5):E521.

PMid:28534820

5. Lagouge M, Larsson NG. The role of mitochondrial DNA mutations and free radicals in disease and ageing. $\mathrm{J}$ Intern Med. 2013;273(6):529-43. https://doi.org/10.1111/joim.12055 PMid:23432181

6. Small DM, Coombes JS, Bennett N, Johnson DW, Gobe GC Oxidative stress, anti-oxidant therapies and chronic kidney disease. Nephrology (Carlton). 2012;17(4):311-21. https://doi. org/10.1111/j.1440-1797.2012.01572.x

PMID: 22288610

7. Li G, Chen Y, Hu H, Liu L, Hu X, Wang J, et al. Association between age-related decline of kidney function and plasma malondialdehyde. Rejuvenation Res. 2012;15(3):257-64. https://doi.org/10.1089/rej.2011.1259

PMID: 22530729

8. Rowland AS, Gorman SA, Thoma RJ, Annett RA, McGrew CA, Yeo RA, et al. Respond. Am J Public Health. 2018;108(7):e12-3. https://doi.org/10.2105/ajph.2018.304443

9. Tomino Y. Enzyme anibody method In: Laboratory Techniques in Renal Cell and Molecular Biology. Tokyo, Japan: Bunkodo Co., Ltd; 2000. p. 82-93.

10. LeBlanc JG, del Carmen S, Miyoshi A, Azevedo V, Sesma F, Langella $\mathrm{P}$, et al. Use of superoxide dismutase and catalase producing lactic acid bacteria in TNBS induced Crohn's disease in mice. J Biotechnol. 2011;151(3):287-93. https://doi. org/10.1016/j.jbiotec.2010.11.008 PMid:21167883

11. Lee J, Hwang KT, Chung MY, Cho D, Park, C. Resistance of Lactobacillus casei KCTC 3260 to reactive oxygen species (ROS): Role for a metal ion chelating effect. J Food Sci. 2005;70:m388-91. https://doi.org/10.1111/j.1365-2621.2005. tb11524.x

12. Ahire JJ, Mokashe NU, Patil HJ, Chaudhari BL. Antioxidative potential of folate producing probiotic Lactobacillus helveticus CD6. J Food Sci Technol. 2013;50(1):26-34. https://doi. org/10.1007/s13197-011-0244-0

PMid:24425884 